\title{
RISKS ASSOCIATED IN RELATED CONTRACTS WITHIN PROJECT FINANCING IN CONSTRUCTION PROJECTS
}

\author{
Siddharth Nahta ${ }^{1}$ \\ ${ }^{l}$ MSc Civil Engineering (Infrastructure Project Management), National University of Singapore, Singapore
}

\begin{abstract}
Lending loan for project financing exposes the lender of many risks involved in the related contracts within project financing. To safeguard themselves from these risks Lenders generally put in a lot of efforts to minimise the affect of these risks. We will discuss the scope and effectiveness of the efforts that help to protect the lenders to suffer from losses with the help of different related contracts and examples.
\end{abstract}

Key Words: Contractors, project financing, related contracts, indemnity. ***.-

\section{INTRODUCTION}

Lending loan for project financing exposes the lender of many risks involved in the related contracts within project financing in construction projects. To safeguard themselves from these risks Lenders generally put in a lot of efforts to minimize the affect of these risks. The paper will focus on some of the major relative contracts in project financing of construction projects.

\section{CONTRACTS BETWEEN BORROWER AND}

\section{DEVELOPER}

Contract between the Borrower (if Contractor) and the developer. This is a related contract and can affect the overall project financing loan contract.

Example-

The respondents obtained a loan from the appellant to partfinance their purchase of a shop lot from a developer. They paid X, being the difference between the purchase price and the loan sum, direct to the developer and then signed a loan agreement cum deed of assignment ('the LACA') absolutely assigning to the appellant all their rights, title and interest in the property under their sale and purchase agreement ('the SPA') with the developer as security for the loan.

When the respondents gave their consent to the developer to charge the master title to Bank, the risk that the said bank may foreclose the land and their property was a risk, which the respondents shouldered. And the fact that the respondents expressly consented to the developer charging the master title to the said bank meant that the respondents were willing to shoulder the risk of foreclosure on the master title in the event that the developer defaulted in paying the loan and the potential loss of the property arising from the foreclosure.

The borrower had an agreement with the developer to charge the master title to the Bank as a loan security.
Developer's default in loan agreement led to bank's applying for termination of contract and suing the respondent for repayment. The judgement was passed in favour of the appellant with the respondent having to repay with interest.

Such default/misunderstandings between the borrower and developer affects the Lender and thus he should be secured from the miss-happenings. Some of the efforts that the lender can apply in such cases are - perfecting security by proper valuation, personal guarantee of the borrower in case of default.

\section{CONTRACT BETWEEN LENDER AND DESIGNATED FIRM TO IDENTIFY BORROWER'S IDENTITY AND ABILITY.}

The related contract between the lender and other parties in a loan contract can also affect the overall contract and the lender should take proper steps to minimise the risks involved in such contracts by adding indemnifying contract to indemnify the lender if the party fails to fulfil a vital obligation towards the lender.

\section{Example-}

A Bank had approved two housing loans to the borrower for sale and purchase of two apartment units by the borrower from the vendor who claimed to be the original purchaser from the owner. To prepare the loan security, the bank had appointed and instructed a legal firm ' $\mathrm{X}$ '. Only after confirmation from the firm that the Bank was 'well protected' from any chances of fraud, the Bank released the loan amount.

But when there was no repayment from the borrower, the Bank got to know that the borrower was a fictitious identity, the vendor was never the beneficial owner of the properties and the solicitor who was witnessing the legal proceedings 
was also from a bogus firm. So, the bank filed a case against the firm for losses and damages incurred by it. This was because the firm failed to investigate the borrower, vendor, proprietor, and developer, which eventually resulted in a heavy loss to the bank, as they could not recover from the security, which too turned out to be fake.

\section{Loss and Damages}

No monthly payment received by the bank

Worthless security deposit papers

Borrower cannot be traced

The case is a perfect example of how crucial it is to properly assess the borrower and as the bank had allotted this work to the firm, the firm following the judgement indemnified the bank from any losses and damages in this case. Indemnity clause between the lender and the firm in these cases plays a vital role in safeguarding the lender.

\section{CONTRACT BETWEEN LENDER AND FIRM TO CONDUCT PROPER}

\section{FEASIBILITY STUDY.}

Lenders usually assign firms (other parties) to do a feasibility study of the project before assigning funds for financing the project. Therefore, it becomes the firm's responsibility to properly assess the project details and come up with a detailed and appropriate estimate of the project. The lenders (Banks) thus depend on the report submitted by the firm and decide whether to allow the project-financing contract or reject it.

Therefore, In case the lender permits the flow of funds to the project and later on finds out that the feasibility study by the firm was improper, it can lead to heavy losses to the lender. To safeguard itself from such happenings, the Lender should always add the indemnity clause in the contract between the lender and the firm thus safeguarding it from any miss happenings occurring due to the firm.

\section{LENDER'S CONTRACT WITH FIRM TO} CONDUCT VALUATION ON SECURITY.

Usually for the project financing which include huge amounts, Lenders assign firms to conduct a study on valuation of the security that the borrower provides to the lender for obtaining project financing. This itself is a related contract and can affect the lenders in case of default by the firm.

\section{Example-}

The defendants, as valuers, were required by the plaintiffs to value properties on the security of which they were considering advancing money on mortgage. The defendants considerably overvalued the property. Following the valuations, the loans were made, which they would not have been if the plaintiffs had known the true values of the properties. The borrowers subsequently defaulted, and in the meantime the property market had fallen substantially, greatly increasing the losses eventually suffered by the plaintiffs. The plaintiffs brought actions against the defendants for damages for negligence and breach of contract. The plaintiffs claimed as damages the outstanding amount of the loan less net recovery from realisation of the security plus unpaid interest.

Thus, The Lender should always add the indemnity clause in the contract between the lender and the firm thus safeguarding it from any miss happenings occurring due to the firm.

Example 2-

The syndicate lenders enter into loan agreement and insurance policies and gemstones were taken into security. A reputable firm of, acting as the banks' agent, arranged all the insurances. The valuation of the insurance policies and gemstones was done by the bank's agent (firm) and only after the valuation report about the security from the firm was done, the banks were ready to pass the loan amount. It was later on found out that the firm over estimated the insurance cover and value of gemstones. The borrowing companies defaulted on the loan. The insurance cover and the gemstones had very little value.

The borrower's insurance company had been in breach of their duty of the utmost good faith to the banks by failing to disclose the brokers' deception to them as the insurers knew about brokers' deliberate moves.

In this case the lenders were safeguarded by the breach of good faith clause by the insurers. To minimise the risks involved in such contracts, the lenders should add indemnifying contract to indemnify the lender if the party fails to fulfil a vital obligation towards the lender.

\section{BORROWER'S CONTRACT WITH PROJECT CONSULTANT}

Developer's contract with the project consultant is a related contract within project financing and affects the overall loan contract. Project consultant generally provides designs and other technical supports to the project. Any fault from his side directly affects the project financing loan contract and subsequently affects the lender.

\section{Example-}

In this case, the developer engaged a company to provide civil and structural engineering services for the construction of the hotel. So, the contractor was to get design drawings from them. But, the contractor was not provided with the correct designs, which was found later on, leading to overall delay of the project. 
Therefore, developers filed its writ of summons against consultant for losses incurred due to delay in project, including loan, interest, etc. The respondents admitted liability and the judgment were ordered for them to pay the liquidated damages incurred by the appellants due to the delay caused.

Therefore, the developer should always add indemnity clause where the project consultant agrees to pay all the losses and damages if at all it happens due to his mistake.

\section{JOINT VENTURE CONTRACT}

If the dispute arises between the joint ventures of the project, it can have an impact on project financing and lenders are at risk.

Example-

In this case, the appellant and repellent enter into a joint venture for a project, but it was later found out that one of the parties did not include many things in the feasibility report that was shown to earlier that could impact its costing which eventually led to the dispute and finally the joint venture was broken.

The joint venture agreement can affect the lender in case of project financing. This is a related contract risk and can affect the project-financing contract. The lenders (bank) should safeguard itself from these situations by taking enough security and assigning responsibility to guarantors in such cases.

\section{BORROWER'S CONTRACT WITH INSURANCE COMPANY}

Borrowers contract with the insurance company in a project is a related contract in project financing. The insurance may affect the lender. Usually, in a project financing the lenders share the insurance as the security to safeguard them in case of non-payment from the borrower.

\section{Example-}

The syndicate lenders enter into loan agreement and insurance policies and gemstones were taken into security. A reputable firm, acting as the banks' agent, arranged all the insurances. The valuation of the insurance policies and gemstones was done by the bank's agent (firm) and only after the valuation report about the security from the firm was done, the banks were ready to pass the loan amount. It was later on found out that the firm over estimated the insurance cover and value of gemstones. The borrowing companies defaulted on the loan. The insurance cover and the gemstones had very little value.

The court gave the judgement that banks be paid for damages by the insurers and the broker. The borrower's insurance company had been in breach of their duty of the utmost good faith to the banks by failing to disclose the brokers' deception to them as the insurers knew about brokers deliberate moves.

In this case the lenders were safeguarded by the breach of good faith clause. The lenders should always add the indemnity clause so that if any defaults from these firms occur, the lenders get totally indemnified from all the losses.

\section{CONTRACT WITH INVESTMENT BROKER}

Some of the lenders and the borrowers do have investment brokers to get clients in relation to loan/project financing. This is a related contract and can affect both the borrower and the lender because the parties then rely on the investment broker to get information about the other party.

\section{Example-}

In this case, the defendant is the investment broker who acts as an agent for the borrower and provides the plaintiff (borrower) with the financing facilities from the lender. The plaintiff relied on the advice of the investment broker to get into contract with the lender for financing facilities. But, the plaintiff suffered because of the repeated delays and there was no progress in the financing facility.

The judgement was given in favour of plaintiff and the brokers were held liable to pay for the losses to the plaintiff.

The above case shows the risk to the borrower but the same can be the case with the lender in a project financing situation where the broker may deceive/fraud the lender for example - by arranging clients for lenders who are not capable, portraying false identity of the borrower etc. to provide the deal to the lender and thus can lead to heavy losses.

Therefore, in a same situation where lender is at risk, the lender should always add indemnity clause in the contract with the broker to ensure itself from any such cases.

\section{SYNDICATE LENDERS CONTRACT}

There are many cases where syndicate lenders do the project financing which itself pose a risk to the loan and is a related contract within project financing. For example, 1) some lenders may go bankrupt,2) Fraud by lenders, etc.

The project financing in many cases involve many lenders and all are at risk with the acts of the syndicate lenders. Hence, to protect itself from such happenings, the lenders should add indemnity clause in the contract between the syndicate lenders. This will help if one of the lenders is in default of his obligations.

\section{CONCLUSION}

The paper in a short and crisp form explained about various risks involved in project financing of construction contracts. The paper is explained in simple language so that it is easy for anyone to understand the importance of having knowledge about related contracts in project financing. 


\section{REFERENCES}

[1] Aseambankers Malaysia Bhd \& Ors v Shencourt Sdn Bhd \& Anor in Court of Appeal (Putrajaya) of 2009

[2] BANQUE KEYSER ULLMANN S.A. V. SKANDIA (U.K.) INSURANCE CO. LTD. AND OTHER

[3] Benichou v Mauritius Commercial Bank [2007] UKPC

[4] Casil Clearing Ltd v. Chinluck Properties Ltd and another [2004] HKCFI 633; HCA 11008/1997 (30 July 2004)

[5] Hartela Contractors Ltd v Hartecon JV Sdn Bhd \& Anor

[6] Hong Leong Bank Berhad v Merces Builders Sdn Bhd $\&$ Ors [2007]

[7] Robertson Quay Investment Pte Ltd v Steen Consultants Pte Ltd and another

[8] SOUTH AUSTRALIA ASSET MANAGEMENT CORPORATION Respondents and YORK MONTAGUE LTD. Appellants UNITED BANK OF KUWAIT PLC. Respondents and PRUDENTIAL PROPERTY SERVICES LTD. Appellants NYKREDIT MORTGAGE BANK PLC. Respondents and Appellants

\section{BIOGRAPHIES}

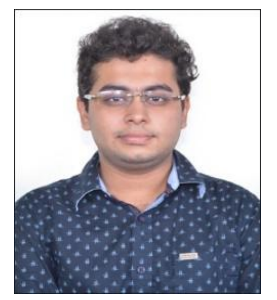

MSc Civil Engineering

(Infrastructure Project Management)

National University of Singapore,

Singapore 